\title{
Beyond peroxisome proliferator-activated receptor $\gamma$ signaling: the multi-facets of the antitumor effect of thiazolidinediones
}

\author{
J-R Weng ${ }^{1,2}, C-Y$ Chen $^{3,4}, J$ J Pinzone ${ }^{5}, M D$ Ringel ${ }^{5}$ and C-S Chen ${ }^{6}$ \\ ${ }^{1}$ Department of Biological Science and Technology, China Medical University, Taichung 404, Taiwan \\ ${ }^{2}$ China Medical University Hospital, Taichung 404, Taiwan \\ ${ }^{3}$ Department of Family Medicine, College of Medicine, National Taiwan University, Taipei, Taiwan \\ ${ }^{4}$ Division of Gerontology Research, National Health Research Institutes, Taipei, Taiwan \\ ${ }^{5}$ Divisions of Endocrinology and Oncology, Department of Internal Medicine and ${ }^{6}$ Division of Medicinal Chemistry and Pharmacognosy, \\ College of Pharmacy, Parks Hall, Ohio State University, 500 West 12th Avenue, Columbus, Ohio 43210, USA
}

(Requests for offprints should be addressed to C-S Chen; Email: chen.844@osu.edu

\begin{abstract}
Certain members of the thiazolidinedione (TZD) family of the peroxisome proliferator-activated receptor $\gamma$ (PPAR $\gamma$ ) agonists, such as troglitazone and ciglitazone, exhibit antitumor activities; however, the underlying mechanism remains inconclusive. Substantial evidence suggests that the antiproliferative effect of these TZD members in cancer cells is independent of PPAR $\gamma$ activation. To discern the role of PPAR $\gamma$ in the antitumor effects of TZDs, we have synthesized PPAR $\gamma$ inactive TZD analogs which, although devoid of PPAR $\gamma$ activity, retain the ability to induce apoptosis with a potency equal to that of their parental TZDs in cancer cell lines with varying PPAR $\gamma$ expression status. Mechanistic studies from this and other laboratories have further suggested that troglitazone and ciglitazone mediate antiproliferative effects through a complexity of PPAR $\gamma$-independent mechanisms. Evidence indicates that troglitazone and ciglitazone block $\mathrm{BH} 3$ domain-mediated interactions between the anti apoptotic Bcl-2 (B-cell leukemia/lymphoma 2) members Bcl-2/Bcl-xL and proapoptotic $\mathrm{Bcl}-2$ members. Moreover, these TZDs facilitate the degradation of cyclin D1 and caspase-8-related FADD-like IL-I-converting enzyme (FLICE)-inhibitory protein through proteasome-mediated proteolysis, and down-regulate the gene expression of prostate-specific antigen gene expression by inhibiting androgen activation of the androgen response elements in the promoter region. More importantly, dissociation of the effects of TZDs on apoptosis from their original pharmacological activity (i.e. PPAR $\gamma$ activation) provides a molecular basis for the exploitation of these compounds to develop different types of molecularly targeted anticancer agents. These TZD-derived novel therapeutic agents, alone or in combination with other anticancer drugs, have translational relevance in fostering effective strategies for cancer treatment.
\end{abstract}

Endocrine-Related Cancer (2006) 13 401-413

\section{Introduction}

Thiazolidinediones (TZDs), including troglitazone (Rezulin), rosiglitazone (Avandia), pioglitazone (Actos), and ciglitazone, are synthetic ligands for the peroxisome proliferator-activated receptor $\gamma$ (PPAR $\gamma$ ) (for review see Day 1999) (Fig. 1). This family of PPAR $\gamma$ agonists improves insulin sensitivity by increasing transcription of certain insulin-sensitive genes involved in the metabolism and transport of lipids in adipocytes, such as lipoprotein lipase, adipocyte fatty acid-binding protein, acyl-CoA synthase, and fatty acid transport protein (Koeffler 2003). In addition, TZDs have been demonstrated to promote the differentiation of preadipocytes by mimicking certain genomic effects of insulin on adipocytes (Tontonoz et al. 1994), and to regulate glucose homeostasis (Saltiel \& Olefsky 1996). Consequently, the TZDs offer a new type of oral therapy in type II diabetes to reduce insulin resistance and to assist glycemic control.

Recent evidence indicates that certain TZD members, especially troglitazone and ciglitazone, exhibit moderate antiproliferative activities against 
The TZD family of PPAR $\gamma$ agonists

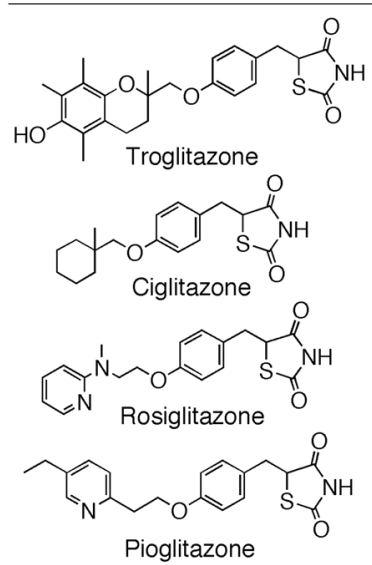

PPAR $\gamma$-inactive TZDs
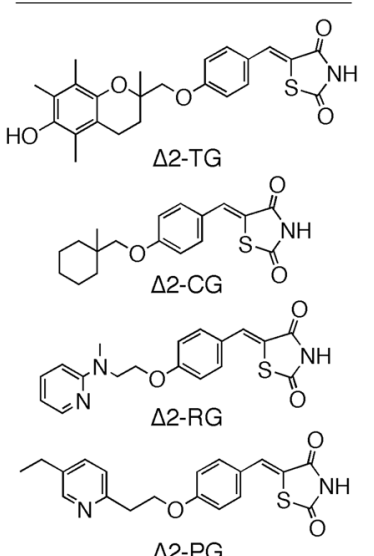

$\triangle 2-P G$

Figure 1 Chemical structures of troglitazone, ciglitazone, rosiglitazone, and pioglitazone, and their respective PPAR $\gamma$-inactive $\Delta 2$ derivatives ( $\Delta 2-\mathrm{TG}, \Delta 2-\mathrm{CG}, \Delta 2-\mathrm{RG}$, and $\Delta 2-P G)$. The introduction of the double bond adjoining the terminal thiazolidinedione ring results in the abrogation of the PPAR $\gamma$ ligand property.

many epithelial-derived human cancer cell lines including those of prostate (Kubota et al. 1998), breast (Yin et al. 2001), colon (Kato et al. 2004), thyroid (Ohta et al. 2001), lung (Tsubouchi et al. 2000), and pituitary carcinoma (Heaney et al. 2003). This growth inhibition was linked to the G1 phase cell cycle arrest through the up-expression of the cyclin-dependent kinase inhibitors p21 and p27 (Koga et al. 2001, 2003, Takeuchi et al. 2002, Yoshizawa et al. 2002, Bae et al. 2003) and/or repression of cyclin D1 expression (Wang et al. 2001, Yin et al. 2001, Lapillonne et al. 2003, Qin et al. 2003). Meanwhile, data from this and other laboratories have indicated that normal prostate epithelial cells (not shown) and T lymphocytes (Harris \& Phipps 2002) are more resistant to apoptotic induction by these TZDs. In the light of this cancer-specific effect, the potential use of these PPAR $\gamma$ agonists as chemopreventive agents has received much attention (for a review see Badawi \& Badr 2002, Kopelovich et al. 2002, Smith \& Kantoff 2002, Bull 2003, Koeffler 2003, Leibowitz \& Kantoff 2003, Grommes et al. 2004, Jiang et al. 2004). Moreover, animal model studies have demonstrated the in vivo efficacy of troglitazone in colon, prostate, and liver cancers (Kubota et al. 1998, Sarraf et al. 1998, Yu et al. 2006) and that of rosiglitazone in pituitary tumors (Henry et al. 2000, Heaney et al. 2002). Despite these advances, the mechanism underlying the antitumor effects of TZD remains unclear. As PPAR $\gamma$-mediated effects of TZDs promote the differentiation of preadipocytes, one school of thought attributes the

same mechanism to the terminal differentiation and cell cycle arrest of tumor cells (Tontonoz et al. 1997). However, the PPAR $\gamma$-target genes that mediate the antiproliferative effects remain elusive, as genomic responses to PPAR $\gamma$ activation in cancer cells are highly complicated (Gupta et al. 2001). Reported causal mechanisms include attenuated expression of protein phosphatase 2A (Altiok et al. 1997), cyclins D1 and E, inflammatory cytokines and transcription factors (Koeffler 2003), and increased expression of an array of gene products linked to growth regulation and cell maturation (Gupta et al. 2001).

On the other hand, several lines of evidence have suggested that the inhibitory effect of TZDs on tumor cell proliferation is independent of PPAR $\gamma$ activation. For example, sensitivity of cancer cells to TZD-induced growth inhibition does not correlate with the level of PPAR $\gamma$ expression, and there exists a three orders of magnitude discrepancy between the concentration required to produce antitumor effects and that to modify insulin action (Day 1999). In addition, the in vitro antitumor effects appear to be structure specific irrespective of their potency in PPAR $\gamma$ activation, i.e. troglitazone and ciglitazone are active while rosiglitazone and pioglitazone are not. To date, an array of nonPPAR $\gamma$ targets has been implicated in the antitumor activities of troglitazone and/or ciglitazone in different cell systems, which include intracellular $\mathrm{Ca}^{2+}$ stores (Palakurthi et al. 2001), phosphorylating activation of extracellular signal-regulated kinases (Gouni-Berthold et al. 2001, Takeda et al. 2001), c-Jun N-terminal protein kinase, and p38 (Bae \& Song 2003), up-regulation of early growth response-1 (Baek et al. 2003), the cyclin-dependent kinase $(\mathrm{CDK})$ inhibitors p27 ${ }^{\text {kipl }}$ (Motomura et al. 2000) and $\mathrm{p} 21^{\mathrm{WAF} / \mathrm{CIP} 1}$ (Sugimura et al. 1999), the tumor suppressor protein p53 and the p53responsive stress protein Gadd45 (Okura et al. 2000), and altered expression of B-cell leukemia/ lymphoma 2(Bcl-2) family members (Bae \& Song 2003). However, some of these targets appear to be cell type specific due to differences in signaling pathways regulating cell growth and survival in different cell systems.

In considering the translational potential of using PPAR $\gamma$ ligand in cancer prevention and therapy, our research has focused on elucidating the mechanisms underlying the antitumor effect of TZDs. In the following sections, evidence that dissociates the effect of TZDs on apoptosis from PPAR $\gamma$-activating activity is presented. This review also provides an 
overview of recent findings from this and other laboratories concerning plausible PPAR $\gamma$-independent targets that underlie TZD-mediated apoptosis. Equally importantly, the use of TZDs as a molecular platform to develop novel mechanism-based therapeutic agents will be discussed.

\section{Demonstration of PPAR-independent antiproliferative effects of TZDs}

We hypothesized that if TZDs mediate antitumor effects independently of PPAR $\gamma$, one would be able to dissociate these two pharmacological activities via structural modifications of these molecules. This premise was corroborated by the development of a novel class of PPAR $\gamma$-inactive TZD analogs, which was accomplished by introducing a double bond adjoining the terminal thiazolidine-2,4-dione ring (Fig. 1) (Shiau et al. 2005). Two lines of evidence indicate that this structural modification abrogated the ligand-binding ability of PPAR $\gamma$. First, these $\Delta 2$ analogs (5-[4-(6-hydroxy-2,5, 7,8-tetramethyl-chroman-2-yl-methoxy)-benzylidene]2,4-thiazolidinedione $\quad(\Delta 2-\mathrm{TG}), \quad 5-\{4-[2-(m e t h y l-$ pyridin-2-yl-amino)-ethoxy]-benzylidene $\}$-2,4-thiazolidinedione $(\Delta 2-\mathrm{RG}), \quad 5-\{4$-[2-(5-ethyl-pyridin-2-yl)ethoxy]-benzylidene $\}$-2,4-thiazolidinedione $(\Delta 2-\mathrm{PG})$, and (5-[4-(1-methyl-cycohexylmethoxy)-benzylidene]thiazolidine-2,4-dione $(\Delta 2-\mathrm{CG})$ ) were inactive in PPAR $\gamma$ activation according to a PPAR $\gamma$ transcription factor ELISA (Shiau et al. 2005). Secondly, DU-145 prostate cancer cells were transfected with a reporter construct that contains PPAR response element (PPRE) upstream of a luciferase gene. None of these $\Delta 2$ derivatives elicited any significant PPAR $\gamma$ transactivation. The loss of PPAR $\gamma$ activity was presumably attributed to the structural rigidity, as a result of the double bond introduction surrounding the heterocyclic system.

These PPAR $\gamma$-inactive TZD derivatives were examined in two prostate cancer cell lines with distinct PPAR $\gamma$ expression status, androgen-independent PC-3 and androgen-dependent LNCaP. Between these two cell lines, PPAR $\gamma$ was highly expressed in PC-3 cells, but was deficient in LNCaP cells (Fig. 2A). Nevertheless, despite a deficiency in PPAR $\gamma, \mathrm{LNCaP}$ cells exhibited a higher degree of susceptibility to troglitazone-mediated in vitro antitumor effects compared with the PPAR $\gamma$-rich PC-3 cells (Fig. 2B, left panel). In addition, $\Delta 2-$ $\mathrm{TG}$, although devoid of PPAR $\gamma$-activating activity, was more potent than troglitazone in suppressing cell proliferation in both cell lines. This growth inhibition was attributable to apoptotic death, as evidenced by mitochondrial cytochrome c release in PC-3 cell (Fig. 2B, right panel).

Similar results were obtained with ciglitazone and $\Delta 2-C G$ with respect to cytochrome c-dependent apoptotic death in PC-3 cells (Fig. 3), with relative potency similar to that of troglitazone and $\Delta 2-\mathrm{TG}$. In contrast, rosiglitazone, pioglitazone, and their $\Delta 2$ derivatives showed marginal effects, even at $50 \mu \mathrm{M}$, on cell death in PC-3 cells (Fig. 3).

Together, these data suggest that TZDs mediated apoptosis induction in prostate cancer cell systems irrespective of PPAR $\gamma$ activation. Mechanistic studies from this and other laboratories have further suggested that TZDs mediate proapoptotic effects through a complexity of PPAR $\gamma$-independent molecular targets, which include, but are not limited to, Bcl-2/Bcl-xL, cyclin D1, FADD-like IL-1-converting enzyme (FLICE)-inhibitory protein (FLIP), and prostate specific antigen (PSA), which are summarized as follows.

\section{TZD-induced apoptosis involves the inhibition of Bcl-xL and Bcl-2 function}

The functional relationship between antiapoptotic and proapoptotic $\mathrm{Bcl}-2$ members in the regulation of mitochondrial integrity is well documented (Cory et al. 2003). Bcl-2 and Bcl-xL mediate their antiapoptotic function through the sequestration of $\mathrm{Bad}$, $\mathrm{Bax}$, and other proapoptotic Bcl-2 members via BH3 domain-facilitated heterodimerization, thereby abrogating their ability to induce mitochondrial cytochrome c release (Diaz et al. 1997, Sattler et al. 1997, Otter et al. 1998, Nouraini et al. 2000, Finnegan et al.2001). Thus, a balance between these two types of Bcl-2 members plays a crucial role in the regulation of the apoptotic machinery.

\section{Effect of troglitazone on the expression of Bcl-2 family members}

It has been reported that troglitazone at high doses repressed Bcl-2 expression in MCF-7 breast cancer (Elstner et al. 1998), and increased the expression level of the proapoptotic proteins $\mathrm{Bad}$ and $\mathrm{Bax}$ in HepG2 hepatoma cells (Bae \& Song 2003). This phenomenon, however, appears to be cell line specific. In our study, troglitazone, even at $30 \mu \mathrm{M}$, did not cause appreciable changes in the expression of any of the aforementioned Bcl-2 members in PC-3 cells with the exception of a slight decrease in Bad expression at 24-h exposure (Fig. 4) (Shiau et al. 2005). 

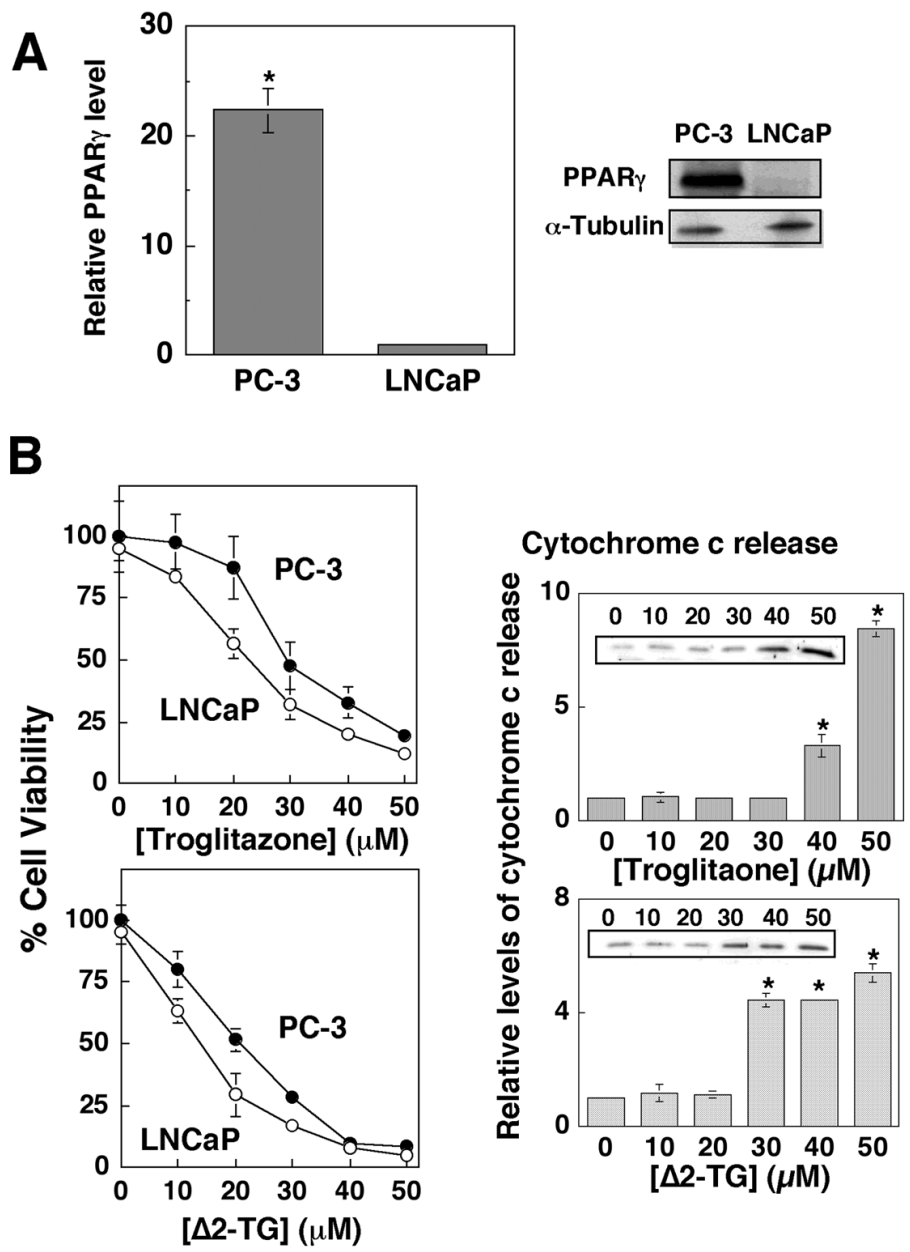

Figure 2 Evidence that the effect of troglitazone on apoptosis in prostate cancer cells is dissociated from PPAR $\gamma$ activation. (A) Western blot analysis of relative PPAR $\gamma$ levels in PC-3 and LNCaP prostate cancer cells. (B, left panels) Dose-dependent effects of troglitazone and $\Delta 2-\mathrm{TG}$ on the cell viability of PC-3 and LNCaP cells in serum-free RPMI 1640 medium for $24 \mathrm{~h}$. Cell viability was assessed by 3-(4,5-dimethylthiazol-2-yl)-2,5-diphenyltetrazolium bromide (MTT) assay; (right panels) levels of cytochrome c release into cytoplasm induced by different doses of troglitazone and $\Delta 2-\mathrm{TG}$ in PC-3 cells under the aforementioned treatment conditions. Values are means \pm S.D. ${ }^{*}, P<0.05$.
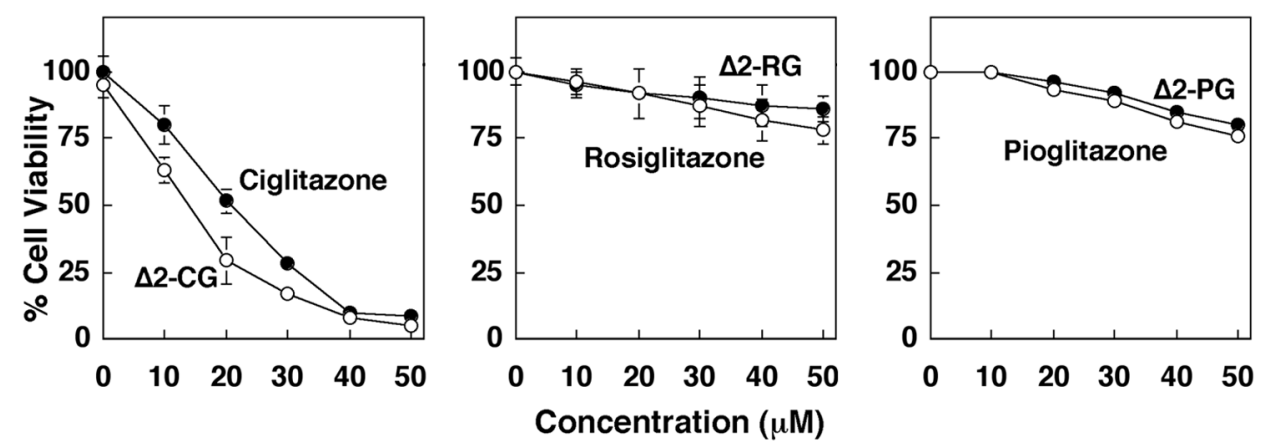

Figure 3 Differential effects of ciglitazone, rosiglitazone, pioglitazone, and their $\Delta 2$ derivatives on apoptotic death in PC-3 cells in serum-free RPMI 1640 medium for $24 \mathrm{~h}$. Values are means \pm S.D. 


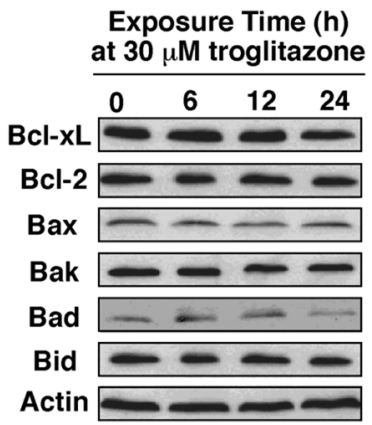

Figure 4 Effect of troglitazone on the expression levels of $\mathrm{Bcl}-2$ family members in PC-3 cells. PC-3 cells were exposed to $30 \mu \mathrm{M}$ troglitazone in serum-free RPMI 1640 medium for the indicated time, and equal amounts of proteins from cell lysates were electrophoresed and probed by western blotting with individual antibodies.

\section{Inhibition of $\mathrm{Bcl}-\mathrm{xL}$ and $\mathrm{Bcl}-2$ function}

Nevertheless, we obtained several lines of evidence that troglitazone and ciglitazone might inhibit the antiapoptotic function of $\mathrm{Bcl}-\mathrm{xL} / \mathrm{Bcl}-2$ by blocking BH3 domain-mediated heterodimerization with proapoptotic Bcl-2 members (Shiau et al. 2005). First, data from the competitive fluorescence polarization analysis suggest that troglitazone, ciglitazone, and their $\Delta 2$ counterparts compete with a Bak BH3domain peptide for binding to Bcl-xL and Bcl-2. Moreover, the potency of TZDs and their $\Delta 2$ analogs in inhibiting this peptide binding correlated with the respective effectiveness in inducing apoptotic death in LNCaP and PC-3 prostate cancer cells (Table 1).

For example, the inability of rosiglitazone and pioglitazone to trigger apoptotic death was reflected in their lack of potency in disrupting interactions between Bcl-xL/Bcl-2 and the Bak BH3 domain. Secondly, troglitazone and $\Delta 2-\mathrm{TG}$ perturbed the dynamics of intracellular $\mathrm{Bcl}-2 / \mathrm{Bak}$ and $\mathrm{Bcl}-\mathrm{xL} /$
Bak interactions in PC-3 cells, i.e. the level of Bak associated with $\mathrm{Bcl}-2$ and $\mathrm{Bcl}-\mathrm{xL}$ was greatly reduced in troglitazone- and $\Delta 2-\mathrm{TG}$-treated cells as compared with DMSO control (Fig. 5A). As a result, liberation of proapoptotic $\mathrm{Bcl}-2$ members induced apoptosis by facilitating cytochrome $\mathrm{c}$ release and consequent caspase-9 activation (Fig. 5B).

Thirdly, overexpression of $\mathrm{Bcl}-\mathrm{xL}$ provided LNCaP cells conferred protection against troglitazone- and $\Delta 2-\mathrm{TG}$-induced apoptosis. As shown in Fig. 5C, ascending expression levels of $\mathrm{Bcl}-\mathrm{xL}$ in three transfected LNCaP stable clones (B11, B1, and B3) diminished the susceptibility to troglitazone- and $\Delta 2$-TG-induced apoptosis death as compared with that of parental LNCaP cells. The extent of cytoprotection conferred by ectopic Bcl$\mathrm{xL}$ correlated with the Bcl-xL expression level. The excessive expression in B3 cells especially completely overcame the apoptotic effect of troglitazone and $\Delta 2-\mathrm{TG}$.

\section{Antiproliferative mechanisms involve modulation of cell cycle effectors}

\section{Troglitazone and ciglitazone repress cyclin D1 expression via proteasome-facilitated proteolysis}

PPAR $\gamma$ agonists, including 15-deoxy- $\Delta 12$, 14-prostaglandin $\mathbf{J}_{2}\left(\mathrm{PGJ}_{2}\right)$, troglitazone, and ciglitazone, at high doses, have been shown to down-regulate cyclin D1 expression as part of their action to cause cell-cycle arrest and growth inhibition in breast cancer cells (Wang et al. 2001, Yin et al. 2001, Lapillonne et al. 2003, Qin et al. 2003, 2004, Huang et al. 2005). Cyclin D1 is a downstream effector of diverse proliferative and transforming signaling pathways, including those mediated by $\beta$-catenin (Shtutman et al. 1999), estrogen receptor

Table 1 Correlation between the $\mathrm{IC}_{50}$ values of individual TZDs and $\Delta 2$-TZDs for inhibiting BH3-mediated interactions of Bcl-xL and $\mathrm{Bcl}-2$ with the Bak $\mathrm{BH} 3$ domain peptide and for inhibiting cell proliferation of PC-3 and LNCaP prostate cancer cells. Values are means \pm S.D.

\begin{tabular}{|c|c|c|c|c|c|c|c|c|c|}
\hline & & TG & $\Delta 2-\mathrm{TG}$ & CG & $\Delta 2-C G$ & $\mathbf{R G}$ & $\Delta 2-R G$ & $P G$ & $\Delta 2-P G$ \\
\hline $\mathrm{IC}_{50}$ in binding inhibition $(\mu \mathrm{M})^{1}$ & $\begin{array}{l}\text { Bcl-xL } \\
\text { Bcl-2 }\end{array}$ & $\begin{array}{l}22 \pm 1 \\
22 \pm 1\end{array}$ & $\begin{array}{l}18 \pm 1 \\
18 \pm 1\end{array}$ & $\begin{array}{l}26 \pm 2 \\
24 \pm 3\end{array}$ & $\begin{array}{l}17 \pm 2 \\
22 \pm 3\end{array}$ & $\begin{array}{l}>50 \\
>50\end{array}$ & $\begin{array}{l}>50 \\
>50\end{array}$ & $\begin{array}{l}>50 \\
>50\end{array}$ & $\begin{array}{l}>50 \\
>50\end{array}$ \\
\hline $\mathrm{IC}_{50}$ in cell viability inhibition $(\mathrm{M})^{2}$ & $\begin{array}{l}\text { PC-3 } \\
\text { LN-CaP }\end{array}$ & $\begin{array}{l}30 \pm 2 \\
22 \pm 3\end{array}$ & $\begin{array}{l}20 \pm 2 \\
14 \pm 1\end{array}$ & $\begin{array}{l}22 \pm 4 \\
\text { n.d. }\end{array}$ & $\begin{array}{l}14 \pm 1 \\
\text { n.d. }\end{array}$ & $\begin{array}{l}>50 \\
\text { n.d. }\end{array}$ & $\begin{array}{l}>50 \\
\text { n.d. }\end{array}$ & $\begin{array}{l}>50 \\
\text { n.d. }\end{array}$ & $\begin{array}{l}>50 \\
\text { n.d. }\end{array}$ \\
\hline
\end{tabular}

${ }^{1}$ Determined by fluorescence polarization analysis of the ability of individual compounds to inhibit the binding of the Flu-BakBH3 peptide with $\mathrm{Bcl}-\mathrm{xL}$ or $\mathrm{Bcl}-2$.

${ }^{2}$ Determined by the MTT assay.

n.d., not determined. 


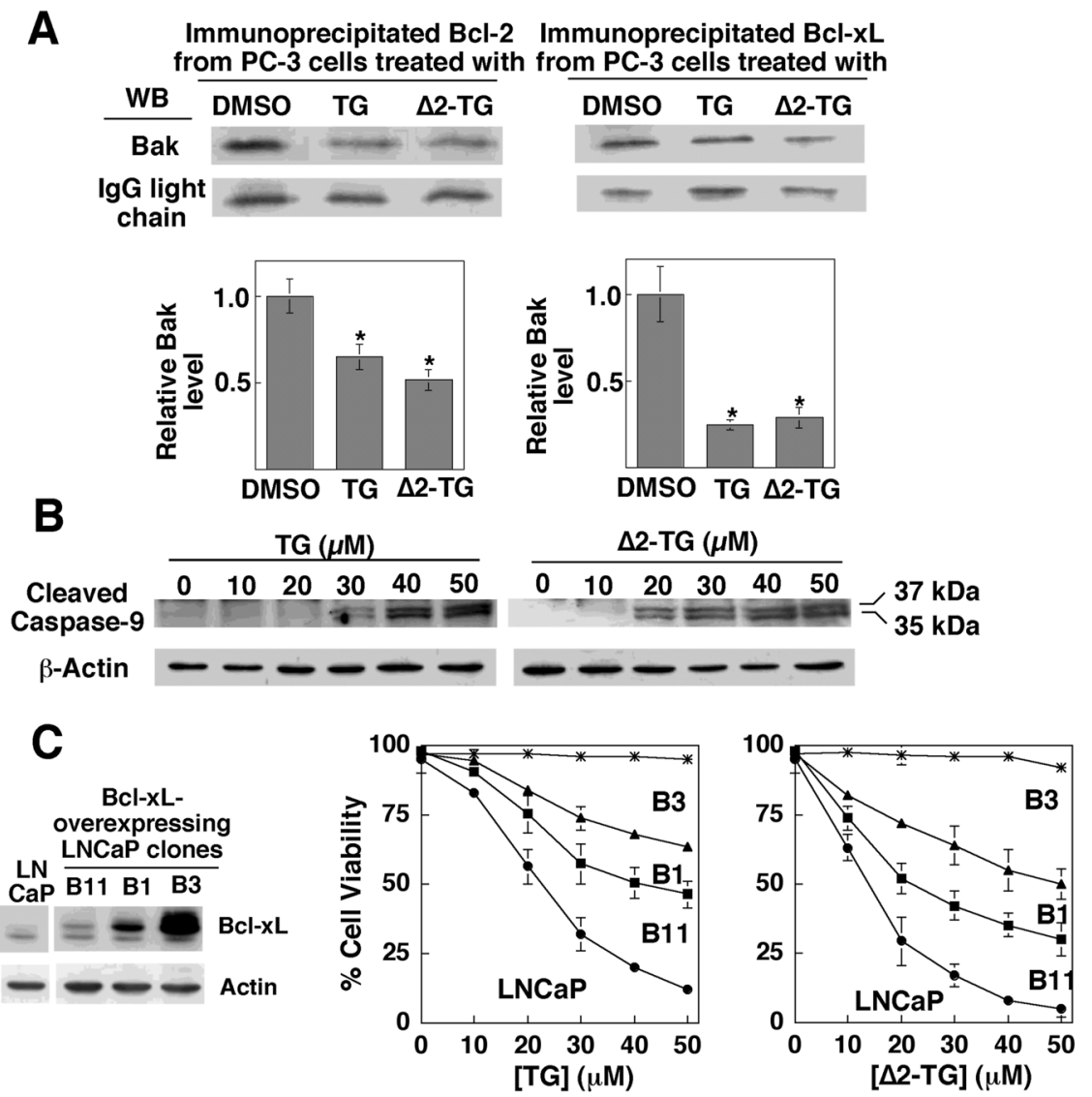

Figure 5 Troglitazone (TG) and $\Delta 2-T G$ trigger caspase-dependent apoptotic death by inhibiting heterodimer formation of Bcl-2 and Bcl-xL with Bak. (A) Effect of TG and $\Delta 2-\mathrm{TG}$ on the dynamics of Bcl-2/Bak (left) and Bcl-xL/Bax (right) interactions in PC-3 cells. $\mathrm{PC}-3$ cells were treated with $50 \mu \mathrm{M}$ TG or $\Delta 2-\mathrm{TG}$ for $12 \mathrm{~h}$, and cell lysates were immunoprecipitated with anti-Bcl-2 or anti-Bcl-xL antibodies. The immunoprecipitates were probed with anti-Bak antibodies by western blot analysis (WB). The bar graphs indicate the relative Bak levels, normalized to IgG light chain levels, in the three treatments. Values are means \pm S.D. $(n=3)$. ${ }^{*} P<0.01$. (B) Dose-dependent effect of TG and $\Delta 2-\mathrm{TG}$ on caspase-9 activation in PC-3 cells. PC-3 cells were treated with TG or $\Delta 2-\mathrm{TG}$ at the indicated concentrations for $24 \mathrm{~h}$. Caspase- 9 antibodies recognize the large subunits ( 35 and $37 \mathrm{kDa})$. (C) Ectopic Bcl-xL protects LNCaP cells from TG- and $\Delta 2$-TG-induced apoptosis by attenuating cytochrome $c$ release in an expression level-dependent manner. (Left panel) Ascending expression levels of ectopic Bcl-xL in B11, B1, and B3 clones by western blot analysis. (Right panel) Dose-dependent effects of TG (left panel) and $\Delta 2$-TG (right panel) on apoptosis in LNCaP, B11, B1, and B3 cells. Data are means \pm S.D. $(n=3)$.

(ER) (Lukas et al. 1996, Wilcken et al. 1997, Prall et al. 1998), Her-2/Neu (Lee et al. 2000), nuclear factor-кB (Joyce et al. 1999, Henry et al. 2000), Rac (Westwick et al. 1997), Ras (Albanese et al. 1995), Src (Lee et al. 1999), signal transducer and activator of transcription (Bromberg et al. 1999, Matsumura et al. 1999), and Wnt (D'Amico et al. 2000). In mammary cells, transcriptional activation of cyclin D1 in response to these mitogenic signals leads to $G_{1} / S$ progression and increased proliferation. Cyclin D1 overexpression has been implicated in oncogene-induced mammary tumorigenesis; it has been noted that more than $50 \%$ of primary breast carcinomas correlated with poor prognosis
(McIntosh et al. 1995, Kenny et al. 1999). In addition to activating cyclin-dependent kinases (CDKs) and sequestering $C D K$ inhibitors in the $G_{1} / S$ transition, the function of cyclin D1 as a CDKindependent activator of $\mathrm{ER} \alpha$ is especially noteworthy (Neuman et al. 1997, Zwijsen et al. 1997, McMahon et al. 1999, Lamb et al. 2000). Cyclin D1 overexpression confers resistance to antiestrogens in breast cancer cells (Musgrove et al. 2001, Hui et al. 2002), and represents a negative predictive factor for tamoxifen response (Stendahl et al. 2004). Together, these findings suggest that an anti-cyclin D1 therapy might be highly specific for treating human breast cancer ( $\mathrm{Yu}$ et al. 2001). An urgent 
need therefore exists to develop potent cyclin D1-ablative agents that are effective in the therapeutically attainable range $(\leq 5 \mu \mathrm{M})$ for breast cancer prevention and/or therapy.

As troglitazone provides an attractive starting point for this drug discovery effort, the mechanism underlying its effect on cyclin D1 repression constituted the focus of our recent investigation (Huang et al. 2005). Several lines of evidence suggest that troglitazone mediates the repression of cyclin D1 expression via a PPAR $\gamma$-independent mechanism. First, $\Delta 2-\mathrm{TG}$ and $\Delta 2-\mathrm{CG}$, although devoid of PPAR $\gamma$ activity, were able to mediate cyclin D1 ablation with slightly higher potency than troglitazone and ciglitazone respectively in MCF-7 breast cancer cells (Fig. 6A), while the more potent $\operatorname{PPAR} \gamma$ agonists rosiglitazone and pioglitazone lacked appreciable activity at comparable concentrations (not shown).

Secondly, troglitazone-mediated cyclin D1 downregulation could not be rescued by the PPAR $\gamma$ antagonist 2-chloro-5-nitro-N-phenylbenzamide (GW9662). Thirdly, despite significantly higher PPAR $\gamma$ expression, MDA-MB-231 breast cancer cells were less susceptible to troglitazone-induced cyclin D1 ablation than MCF-7 cells. Although it has been reported that the PPAR $\gamma$ ligands $\mathrm{PGJ}_{2}$ and troglitazone inhibited cyclin D1 transcription by activating PPAR $\gamma$ in MCF-7 cells (Wang et al. 2001) and mouse skin keratinocytes ( $\mathrm{He}$ et al. 2004) respectively, data from this and other laboratories have indicated that troglitazone and ciglitazone mediate cyclin D1 ablation in MCF-7 cells by facilitating ubiquitination and proteasomal

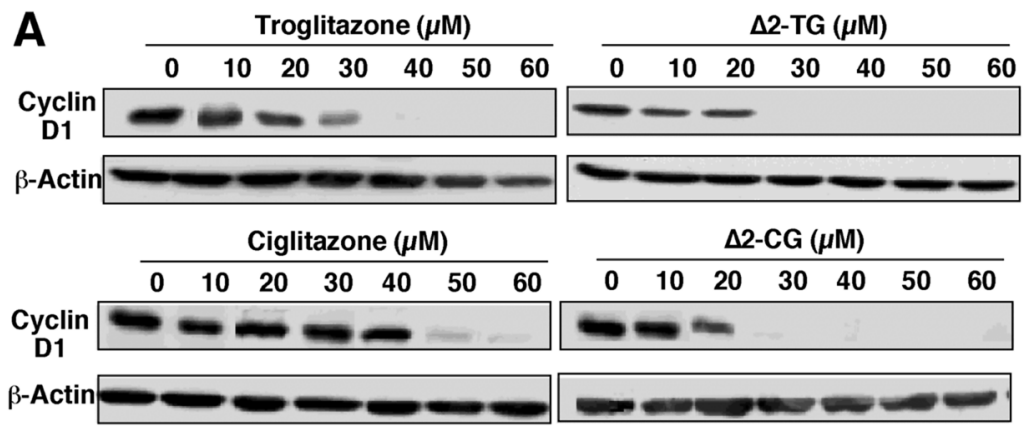

B

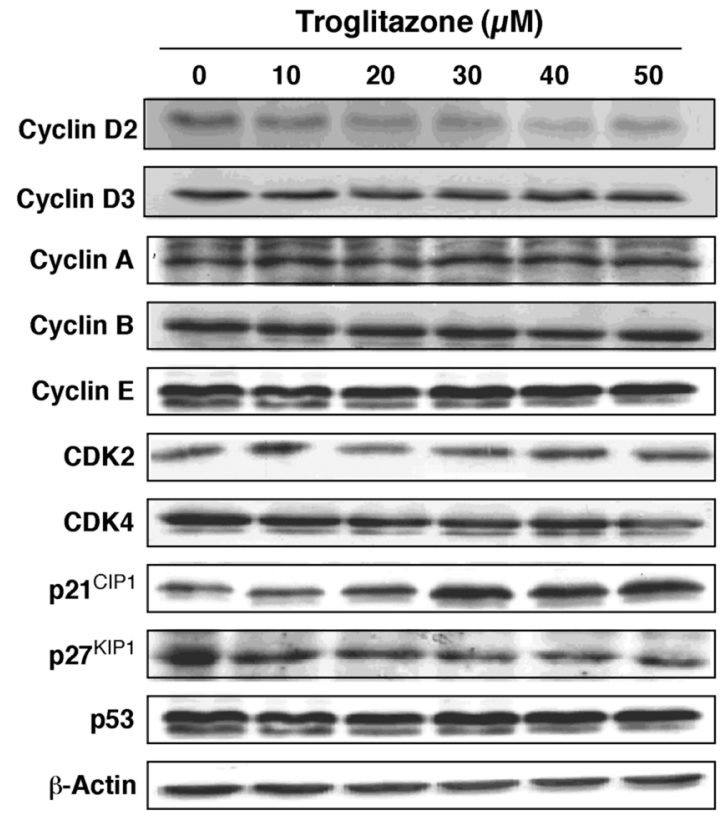

Figure 6 Pharmacological evidence that the effect of troglitazone and ciglitazone on cyclin D1 down-regulation in MCF-7 cells is dissociated from PPAR $\gamma$ activation. (A) Dose-dependent effect of troglitazone and $\Delta 2-\mathrm{TG}$ on cyclin D1 expression for $24 \mathrm{~h}$ in MCF-7 cells by western blotting. (B) Dose-dependent effects of troglitazone on the expression of cyclins and CDKs in MCF-7 cells by western blot analysis. 
proteolysis in a specific manner (Qin et al. 2003, Huang et al. 2005). For example, PCR analysis indicates that the mRNA level of cyclin D1 remained unaltered in drug-treated cells, indicating that the repression was mediated at the post-transcriptional level. Moreover, this drug-induced cyclin D1 repression could be rescued by proteasome inhibitors, and was preceded by increased ubiquitination.

It is noteworthy that the troglitazone-mediated cyclin D1 ablation was highly specific. Among all cyclins and CDKs examined (cyclins D2. D3, A, B, and E, and CDKs 2 and 4) as well as p53, only cyclin D2 and CDK4 showed a slight decrease in the expression level in drug-treated MCF-7 cells (Fig. 6B).

\section{Troglitazone up-regulates the expression of the CDK inhibitor p21 ${ }^{\mathrm{CIP} 1}$}

Moreover, western blotting analysis indicates that, in MCF-7 cells, troglitazone up-regulated the expression of $\mathrm{p} 21^{\mathrm{CIP} 1}$, while $\mathrm{p} 27^{\mathrm{KIP} 1}$ exhibited a dose-dependent decrease (Fig. 6B) (Huang et al. 2005). However, the effect of troglitazone on the expression levels of these two CDK inhibitors varies among different cell lines. For example, troglitazone treatment led to increased expression of both $\mathrm{p} 21^{\mathrm{CIP} 1}$ and $\mathrm{p} 27^{\mathrm{KIP} 1}$ in several hepatocellular carcinoma cells examined (Elnemr et al. 2000, Koga et al. 2001), while in troglitazone-treated pancreatic cancer cells, only the expression level of p2 $7^{\mathrm{KIP} 1}$, but not that of $\mathrm{p} 21^{\mathrm{CIP} 1}$, increased (Motomura et al. 2000, Itami et al. 2001). These findings suggested that variations in responses exist among different cancer cell lines.

\section{Other molecular mechanisms}

In addition to the aforementioned effects, several other PPAR $\gamma$-independent mechanisms have been reported to account for the antiproliferative action of TZDs in different cancer cells. Among these proposed mechanisms, the effects on proteasomemediated degradation of FLIP (Kim et al. 2002) and down-regulation of PSA expression (Kubota et al. 1998, Hisatake et al. 2000) are especially noteworthy in light of their clinical implications in cancer therapy.

FLIP inhibits apoptosis induced by tumor necrosis factor (TNF) family death receptor by blocking caspase 8 activation (Wajant 2003). As demonstrated by antisense-mediated down-regulation, decreased expression of FLIP confers sensitivity against death receptor-induced apoptosis. Inhibition of FLIP expression in tumor cells is of particular importance to TNF-related apoptosis inducing ligand (TRAIL)-based cancer therapy (Wajant 2003). TRAIL is the ligand of death receptors, and has attracted substantial clinical interests in light of its ability to induce apoptosis preferentially in tumor cells. However, not all tumor cells respond to TRAIL, in part because of intracellular resistance mechanisms (Ashkenazi 2002). Recent reports indicate that PPAR $\gamma$ agonists including troglitazone could sensitize tumor cells to TRAIL-induced apoptosis (Goke et al. 2000, Kim et al. 2002) as a result of the proteasome-dependent proteolysis of FLIP (Kim et al. 2002). As the mode of FLIP down-regulation is reminiscent of that of cyclin D1, there may exist cross-reactivity in troglitazonemediated proteasomal degradation of both proteins.

PSA is used as a serum biomarker for diagnosis and progression of prostate cancer (Polascik et al. 1999). It has been shown that troglitazone at concentrations $(\leq 10 \mu \mathrm{M})$ lower than that required for growth inhibition $(\geq 20 \mu \mathrm{M})$ was able to downregulate PSA expression in $\mathrm{LNCaP}$ prostate cancer cells through the inhibition of androgen activation of the androgen response elements in the regulatory region of the PSA gene (Hisatake et al. 2000). Moreover, the same report indicates that troglitazone at $600-800 \mathrm{mg} /$ day stabilized PSA levels in a prostate cancer patient with a radical prostectomy throughout a 14-month period.

\section{Pharmacological exploitation of troglitazone to develop novel mechanism-based anticancer agents}

The above discussion clearly demonstrates that the antiproliferative activity of troglitazone is mediated through multiple molecular targets independently of PPAR $\gamma$. From a mechanistic perspective, dissociation of the aforementioned pharmacological activities from PPAR $\gamma$ activation provide a molecular rationale to use troglitazone as a starting point to develop novel mechanism-based therapeutic agents. The proof of the principle of this premise is 5[4-(6-allyoxy-2,5,7,8-tetramethyl-chroman-2-yl-methoxy)-benzylidene]-2,4-thizolidinedione ( $\Delta 2$-TG-6) (Huang et al. 2005), a close structural analog that exhibited an order of magnitude higher potency than troglitazone and $\Delta 2-\mathrm{TG}$ in repressing cyclin D1 expression and inhibiting MCF-7 cell proliferation (Fig. 7). 

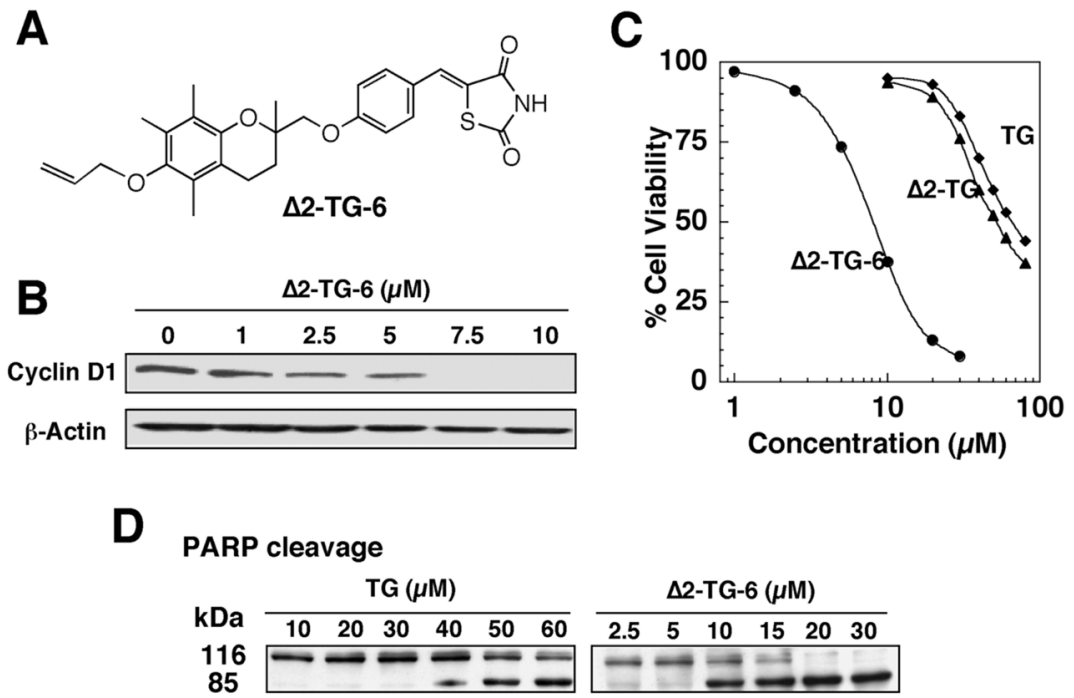

Figure $7 \Delta$ 2-TG-6, a structurally optimized cyclin D1-ablative agent. (A) Structure of $\Delta 2-T G-6$. (B) Dose-dependent effect of $\Delta$ 2-TG-6 on cyclin D1 down-regulation in MCF-7 cells. (C) Dose-dependent effects of $\Delta 2-\mathrm{TG}-6$ versus TG and $\Delta 2-\mathrm{TG}$ on MCF-7 cell viability as analyzed by MTT assay. (D) Dose-dependent effects of $\Delta 2-T G-6$ versus TG on PARP cleavage. PARP proteolysis to the apoptosis-specific $85 \mathrm{kDa}$ fragment was monitored by western blotting.

As shown, $\Delta 2-\mathrm{TG}-6$ reduced cyclin D1 levels at concentrations as low as $2.5 \mu \mathrm{M}$ compared with $\geq 20 \mu \mathrm{M}$ for $\Delta 2-\mathrm{TG}$ (Fig. $7 \mathrm{~B}$ ), and exhibited $\mathrm{IC}_{50}$ of $8 \mu \mathrm{M}$ versus $55 \mu \mathrm{M}$ for $\Delta 2-\mathrm{TG}$ in inhibiting MCF-7 cell viability (Fig. 7C). This antiproliferative effect was attributable to apoptosis induction, as evidenced by poly(ADP-ribose)polymerase (PARP) cleavage (Fig. 7D). Lead optimization of $\Delta 2$-TG-6 to generate more potent cyclin D1-ablative agents is currently undergoing, the clinical implication of which is multifold. First, cyclin D1 ablation provides specific protection against breast carcinogenesis (Yu et al. 2001). Secondly, in light of the role of cyclin D1 overexpression in antiestrogen resistance, cyclin D1 ablation may help overcome the resistance. Thirdly, the synergistic interaction between flavopiridol and trastuzumab in inhibiting breast cancer cell proliferation is attributable, in part, to the reduction of cyclin $\mathrm{D} 1$ expression ( $\mathrm{Wu}$ et al. 2002). These agents may sensitize cells to the antiproliferative action of either $\mathrm{CDK}$ inhibition or Her-2/Akt inhibition.

A similar approach has been taken to develop a potent $\mathrm{Bcl}-2 / \mathrm{Bcl}-\mathrm{xL}$ inhibitor (TG-88) with an $\mathrm{IC}_{50}$ of $1.8 \mu \mathrm{M}$ based on fluorescence polarization analysis. Oral TG-88 at a daily dose of 100 or $200 \mathrm{mg} / \mathrm{kg}$ was effective in suppressing PC-3 xenograft tumor growth without causing weight loss or apparent toxicity, indicating its oral bioavailability and potential clinical use (Shiau et al. 2005). It is also noteworthy that the structural requirement for Bcl-2/Blc-xL inhibition differed from that of cyclin D1 ablation.

\section{Conclusion}

Data from this and other laboratories have clearly demonstrated that the effect of TZDs on triggering apoptosis in cancer cells is dissociated from that of PPAR $\gamma$ activation. To date, a number of important signaling mechanisms have been identified to underlie TZD-mediated antitumor activities, including, but not limited to, inhibition of Bcl-2/Bcl-xL function and repression of the expression of cyclin D1, FLIP, and PSA. These findings provide molecular underpinnings for the molecular exploitation of troglitazone and ciglitazone to develop different types of molecularly targeted anticancer agents. Our data indicate that structural preference for Bcl-2/Bcl-xL inhibition differs from that of cyclin D1 ablation, while that between cyclin D1 and FLIP is currently being investigated. Because of the heterogeneity in the cancer cell population, various genetic lesions/molecular defects allow different subsets of tumor cells to exhibit differential sensitivity to apoptotic signals generated by different chemotherapeutic agents. Thus, these troglitazonederived agents in combination with other therapeutic agents have translational relevance in fostering effective strategies for cancer treatment. 


\section{Acknowledgements}

This work was supported by Public Health Service Grants CA-94829 and CA-112250 (C-S C), and K08CA101875 (JJP) from National Cancer Institute, NIH, Department of Health and Human Service, and by Army Grant W81XWH-05-1-0089 from Department of Defense Prostate Cancer Research Program (C-SC). The authors declare that there is no conflict of interest that would prejudice the impartiality of this scientific work.

\section{References}

Albanese C, Johnson J, Watanabe G, Eklund N, Vu D, Arnold A \& Pestell RG 1995 Transforming p21ras mutants and c-Ets-2 activate the cyclin D1 promoter through distinguishable regions. Journal of Biological Chemistry 270 23589-23597.

Altiok S, Xu M \& Spiegelman BM 1997 PPARgamma induces cell cycle withdrawal: inhibition of E2F/DP DNA-binding activity via down-regulation of PP2A. Genes and Development 11 1987-1998.

Ashkenazi A 2002 Targeting death and decoy receptors of the tumour-necrosis factor superfamily. Nature Review Cancer 2 420-430.

Badawi AF \& Badr MZ 2002 Chemoprevention of breast cancer by targeting cyclooxygenase- 2 and peroxisome proliferator-activated receptor-gamma (Review). International Journal of Oncology 20 1109-1122.

Bae MA \& Song BJ 2003 Critical role of c-Jun N-terminal protein kinase activation in troglitazone-induced apoptosis of human HepG2 hepatoma cells. Molecular Pharmacology 63 401-408.

Bae MA, Rhee H \& Song BJ 2003 Troglitazone but not rosiglitazone induces $\mathrm{G} 1$ cell cycle arrest and apoptosis in human and rat hepatoma cell lines. Toxicology Letters 139 67-75.

Baek SJ, Wilson LC, Hsi LC \& Eling TE 2003 Troglitazone, a peroxisome proliferator-activated receptor gamma (PPAR gamma) ligand, selectively induces the early growth response-1 gene independently of PPAR gamma. A novel mechanism for its anti-tumorigenic activity. Journal of Biological Chemistry 278 5845-5853.

Bromberg JF, Wrzeszczynska MH, Devgan G, Zhao Y, Pestell RG, Albanese C \& Darnell JE Jr 1999 Stat3 as an oncogene. Cell 98 295-303.

Bull AW 2003 The role of peroxisome proliferator-activated receptor gamma in colon cancer and inflammatory bowel disease. Archives of Pathology and Laboratory Medicine $1271121-1123$.

Cory S, Huang DC \& Adams JM 2003 The Bcl-2 family: roles in cell survival and oncogenesis. Oncogene 22 8590-8607.

D'Amico M, Hulit J, Amanatullah DF, Zafonte BT, Albanese C, Bouzahzah B, Fu M, Augenlicht LH, Donehower LA, Takemaru K et al. 2000 The integrin-linked kinase regulates the cyclin D1 gene through glycogen synthase kinase 3 beta and cAMP-responsive element-binding protein-dependent pathways. Journal of Biological Chemistry 275 32649-32657.

Day C 1999 Thiazolidinediones: a new class of antidiabetic drugs. Diabetic Medicine 16 179-192.

Diaz JL, Oltersdorf T, Horne W, McConnell M, Wilson G, Weeks S, Garcia T \& Fritz LC 1997 A common binding site mediates heterodimerization and homodimerization of Bcl-2 family members. Journal of Biological Chemistry 272 11350-11355.

Elnemr A, Ohta T, Iwata K, Ninomia I, Fushida S, Nishimura G, Kitagawa H, Kayahara M, Yamamoto M, Terada T et al. 2000 PPARgamma ligand (thiazolidinedione) induces growth arrest and differentiation markers of human pancreatic cancer cells. International Journal of Oncology 17 1157-1164.

Elstner E, Muller C, Koshizuka K, Williamson EA, Park D, Asou H, Shintaku P, Said JW, Heber D \& Koeffler HP 1998 Ligands for peroxisome proliferator-activated receptorgamma and retinoic acid receptor inhibit growth and induce apoptosis of human breast cancer cells in vitro and in BNX mice. PNAS 95 8806-8811.

Finnegan NM, Curtin JF, Prevost G, Morgan B \& Cotter TG 2001 Induction of apoptosis in prostate carcinoma cells by $\mathrm{BH} 3$ peptides which inhibit Bak/Bcl-2 interactions. British Journal of Cancer 85 115-121.

Goke R, Goke A, Goke B \& Chen Y 2000 Regulation of TRAIL-induced apoptosis by transcription factors. Cellular Immunology 201 77-82.

Gouni-Berthold I, Berthold HK, Weber AA, Ko Y, Seul C, Vetter H \& Sachinidis A 2001 Troglitazone and rosiglitazone induce apoptosis of vascular smooth muscle cells through an extracellular signal-regulated kinase-independent pathway. Naunyn Schmiedeberg's Archives of Pharmacology 363 215-221.

Grommes C, Landreth GE \& Heneka MT 2004 Antineoplastic effects of peroxisome proliferator-activated receptor gamma agonists. Lancet Oncology 5 419-429.

Gupta RA, Brockman JA, Sarraf P, Willson TM \& DuBois RN 2001 Target genes of peroxisome proliferator-activated receptor gamma in colorectal cancer cells. Journal of Biological Chemistry 276 29681-29687.

Harris SG \& Phipps RP 2002 Prostaglandin D(2), its metabolite 15-d-PGJ(2), and peroxisome proliferator activated receptor-gamma agonists induce apoptosis in transformed, but not normal, human T lineage cells. Immunology 105 23-34.

He G, Thuillier P \& Fischer SM 2004 Troglitazone inhibits cyclin D1 expression and cell cycling independently of PPARgamma in normal mouse skin keratinocytes. Journal of Investigative Dermatology 123 1110-1119.

Heaney AP, Fernando M, Yong WH \& Melmed S 2002 Functional PPAR-gamma receptor is a novel therapeutic target for ACTH-secreting pituitary adenomas. Nature Medicine 8 1281-1287.

Heaney AP, Fernando M \& Melmed S 2003 PPAR-gamma receptor ligands: novel therapy for pituitary adenomas. Journal of Clinical Investigation 111 1381-1388. 
Henry DO, Moskalenko SA, Kaur KJ, Fu M, Pestell RG, Camonis JH \& White MA 2000 Ral GTPases contribute to regulation of cyclin D1 through activation of NF-kappaB. Molecular and Cellular Biology 20 8084-8092.

Hisatake JI, Ikezoe T, Carey M, Holden S, Tomoyasu S \& Koeffler HP 2000 Down-regulation of prostate-specific antigen expression by ligands for peroxisome proliferator-activated receptor gamma in human prostate cancer. Cancer Research 60 5494-5498.

Huang JW, Shiau CW, Yang YT, Kulp SK, Chen KF, Brueggemeier RW, Shapiro CL \& Chen CS 2005 Peroxisome proliferator-activated receptor gamma-independent ablation of cyclin D1 by thiazolidinediones and their derivatives in breast cancer cells. Molecular Pharmacology 67 1342-1348.

Hui R, Finney GL, Carroll JS, Lee CS, Musgrove EA \& Sutherland RL 2002 Constitutive overexpression of cyclin D1 but not cyclin E confers acute resistance to antiestrogens in T-47D breast cancer cells. Cancer Research 62 6916-6923.

Itami A, Watanabe G, Shimada Y, Hashimoto Y, Kawamura J, Kato M, Hosotani R \& Imamura M 2001 Ligands for peroxisome proliferator-activated receptor gamma inhibit growth of pancreatic cancers both in vitro and in vivo. International Journal of Cancer 94 370-376.

Jiang M, Shappell SB \& Hayward SW 2004 Approaches to understanding the importance and clinical implications of peroxisome proliferator-activated receptor gamma (PPARgamma) signaling in prostate cancer. Journal of Cellular Biochemistry 91 513-527.

Joyce D, Bouzahzah B, Fu M, Albanese C, D'Amico M, Steer J, Klein JU, Lee RJ, Segall JE, Westwick JK et al. 1999 Integration of Rac-dependent regulation of cyclin D1 transcription through a nuclear factor-kappaB-dependent pathway. Journal of Biological Chemistry 274 25245-25249.

Kato M, Kusumi T, Tsuchida S, Tanaka M, Sasaki M \& Kudo H 2004 Induction of differentiation and peroxisome proliferator-activated receptor gamma expression in colon cancer cell lines by troglitazone. Journal of Cancer Research and Clinical Oncology 130 73-79.

Kenny FS, Hui R, Musgrove EA, Gee JM, Blamey RW, Nicholson RI, Sutherland RL \& Robertson JF 1999 Overexpression of cyclin D1 messenger RNA predicts for poor prognosis in estrogen receptor-positive breast cancer. Clinical Cancer Research 5 2069-2076.

Kim Y, Suh N, Sporn M \& Reed JC 2002 An inducible pathway for degradation of FLIP protein sensitizes tumor cells to TRAIL-induced apoptosis. Journal of Biological Chemistry 277 22320-22329.

Koeffler HP 2003 Peroxisome proliferator-activated receptor gamma and cancers. Clinical Cancer Research 9 1-9.

Koga H, Sakisaka S, Harada M, Takagi T, Hanada S, Taniguchi E, Kawaguchi T, Sasatomi K, Kimura R, Hashimoto $\mathrm{O}$ et al. 2001 Involvement of p21(WAF1/Cip1), p27(Kip1), and p18(INK4c) in troglitazone-induced cell-cycle arrest in human hepatoma cell lines. Hepatology 33 1087-1097.
Koga H, Harada M, Ohtsubo M, Shishido S, Kumemura H, Hanada S, Taniguchi E, Yamashita K, Kumashiro R, Ueno T et al. 2003 Troglitazone induces p27Kip1-associated cell-cycle arrest through down-regulating Skp2 in human hepatoma cells. Hepatology 37 1086-1096.

Kopelovich L, Fay JR, Glazer RI \& Crowell JA 2002 Peroxisome proliferator-activated receptor modulators as potential chemopreventive agents. Molecular Cancer Therapeutics 1 357-363.

Kubota T, Koshizuka K, Williamson EA, Asou H, Said JW, Holden S, Miyoshi I \& Koeffler HP 1998 Ligand for peroxisome proliferator-activated receptor gamma (troglitazone) has potent antitumor effect against human prostate cancer both in vitro and in vivo. Cancer Research 58 3344-3352.

Lamb J, Ladha MH, McMahon C, Sutherland RL \& Ewen ME 2000 Regulation of the functional interaction between cyclin D1 and the estrogen receptor. Molecular and Cellular Biology 20 8667-8675.

Lapillonne H, Konopleva M, Tsao T, Gold D, McQueen T, Sutherland RL, Madden T \& Andreeff M 2003 Activation of peroxisome proliferator-activated receptor gamma by a novel synthetic triterpenoid 2-cyano-3,12-dioxooleana1,9-dien-28-oic acid induces growth arrest and apoptosis in breast cancer cells. Cancer Research 63 5926-5939.

Lee RJ, Albanese C, Stenger RJ, Watanabe G, Inghirami G, Haines GK 3rd, Webster M, Muller WJ, Brugge JS, Davis $\mathrm{RJ}$ et al. 1999 pp60(v-src) induction of cyclin D1 requires collaborative interactions between the extracellular signal-regulated kinase, p38, and Jun kinase pathways. A role for cAMP response element-binding protein and activating transcription factor-2 in pp60(v-src) signaling in breast cancer cells. Journal of Biological Chemistry 274 $7341-7350$.

Lee RJ, Albanese C, Fu M, D’Amico M, Lin B, Watanabe G, Haines GK 3rd, Siegel PM, Hung MC, Yarden Y et al. 2000 Cyclin D1 is required for transformation by activated Neu and is induced through an E2F-dependent signaling pathway. Molecular and Cellular Biology 20 $672-683$.

Leibowitz SB \& Kantoff PW 2003 Differentiating agents and the treatment of prostate cancer: Vitamin D3 and peroxisome proliferator-activated receptor gamma ligands. Seminars in Oncology 30 698-708.

Lukas J, Bartkova J \& Bartek J 1996 Convergence of mitogenic signalling cascades from diverse classes of receptors at the cyclin D-cyclin-dependent kinase-pRb-controlled G1 checkpoint. Molecular and Cellular Biology 16 6917-6925.

McIntosh GG, Anderson JJ, Milton I, Steward M, Parr AH, Thomas MD, Henry JA, Angus B, Lennard TW \& Horne CH 1995 Determination of the prognostic value of cyclin D1 overexpression in breast cancer. Oncogene 11 885-891.

McMahon C, Suthiphongchai T, DiRenzo J \& Ewen ME 1999 $\mathrm{P} / \mathrm{CAF}$ associates with cyclin D1 and potentiates its activation of the estrogen receptor. PNAS 96 5382-5387. 
Matsumura I, Kitamura T, Wakao H, Tanaka H, Hashimoto K, Albanese C, Downward J, Pestell RG \& Kanakura Y 1999 Transcriptional regulation of the cyclin D1 promoter by STAT5: its involvement in cytokine-dependent growth of hematopoietic cells. EMBO Journal 18 1367-1377.

Motomura W, Okumura T, Takahashi N, Obara T \& Kohgo Y 2000 Activation of peroxisome proliferator-activated receptor gamma by troglitazone inhibits cell growth through the increase of $\mathrm{p} 27 \mathrm{KiP} 1$ in human. Pancreatic carcinoma cells. Cancer Research 60 5558-5564.

Musgrove EA, Hunter LJ, Lee CS, Swarbrick A, Hui R \& Sutherland RL 2001 Cyclin D1 overexpression induces progestin resistance in T-47D breast cancer cells despite p27(Kip1) association with cyclin E-Cdk2. Journal of Biological Chemistry 276 47675-47683.

Neuman E, Ladha MH, Lin N, Upton TM, Miller SJ, DiRenzo J, Pestell RG, Hinds PW, Dowdy SF, Brown M et al. 1997 Cyclin D1 stimulation of estrogen receptor transcriptional activity independent of cdk4. Molecular and Cellular Biology 17 5338-5347.

Nouraini S, Six E, Matsuyama S, Krajewski S \& Reed JC 2000 The putative pore-forming domain of Bax regulates mitochondrial localization and interaction with Bcl-X(L). Molecular and Cellular Biology 20 1604-1615.

Ohta K, Endo T, Haraguchi K, Hershman JM \& Onaya T 2001 Ligands for peroxisome proliferator-activated receptor gamma inhibit growth and induce apoptosis of human papillary thyroid carcinoma cells. Journal of Clinical Endocrinology and Metabolism 86 2170-2177.

Okura T, Nakamura M, Takata Y, Watanabe S, Kitami Y \& Hiwada K 2000 Troglitazone induces apoptosis via the p53 and Gadd45 pathway in vascular smooth muscle cells. European Journal of Pharmacology 407 227-235.

Otter I, Conus S, Ravn U, Rager M, Olivier R, Monney L, Fabbro D \& Borner C 1998 The binding properties and biological activities of Bcl-2 and Bax in cells exposed to apoptotic stimuli. Journal of Biological Chemistry 273 6110-6120.

Palakurthi SS, Aktas H, Grubissich LM, Mortensen RM \& Halperin JA 2001 Anticancer effects of thiazolidinediones are independent of peroxisome proliferator-activated receptor gamma and mediated by inhibition of translation initiation. Cancer Research $616213-6218$.

Polascik TJ, Oesterling JE \& Partin AW 1999 Prostate specific antigen: a decade of discovery - what we have learned and where we are going. Journal of Urology 162 293-306.

Prall OW, Rogan EM, Musgrove EA, Watts CK \& Sutherland RL 1998 c-Myc or cyclin D1 mimics estrogen effects on cyclin E-Cdk2 activation and cell cycle reentry. Molecular and Cellular Biology 18 4499-4508.

Qin C, Burghardt R, Smith R, Wormke M, Stewart J \& Safe S 2003 Peroxisome proliferator-activated receptor gamma agonists induce proteasome-dependent degradation of cyclin D1 and estrogen receptor alpha in MCF-7 breast cancer cells. Cancer Research 63 958-964.

Qin C, Morrow D, Stewart J, Spencer K, Porter W, Smith R 3rd, Phillips T, Abdelrahim M, Samudio I \& Safe S 2004 A new class of peroxisome proliferator-activated receptor gamma (PPARgamma) agonists that inhibit growth of breast cancer cells: 1,1-Bis(3'-indolyl)-1-(p-substituted phenyl)methanes. Molecular Cancer Therapeutics 3 247-260.

Saltiel AR \& Olefsky JM 1996 Thiazolidinediones in the treatment of insulin resistance and type II diabetes. Diabetes 45 1661-1669.

Sarraf P, Mueller E, Jones D, King FJ, DeAngelo DJ, Partridge JB, Holden SA, Chen LB, Singer S, Fletcher C et al. 1998 Differentiation and reversal of malignant changes in colon cancer through PPARgamma. Nature Medicine 4 1046-1052.

Sattler M, Liang H, Nettesheim D, Meadows RP, Harlan JE, Eberstadt M, Yoon HS, Shuker SB, Chang BS, Minn AJ et al. 1997 Structure of Bcl-xL-Bak peptide complex: recognition between regulators of apoptosis. Science $\mathbf{2 7 5}$ 983-986.

Shiau CW, Yang CC, Kulp SK, Chen KF, Chen CS \& Huang JW 2005 Thiazolidenediones mediate apoptosis in prostate cancer cells in part through inhibition of Bcl-xL/Bcl-2 functions independently of PPARgamma. Cancer Research 65 1561-1569.

Shtutman M, Zhurinsky J, Simcha I, Albanese C, D'Amico M, Pestell R \& Ben-Ze'ev A 1999 The cyclin D1 gene is a target of the beta-catenin/LEF-1 pathway. PNAS 96 5522-5527.

Smith MR \& Kantoff PW 2002 Peroxisome proliferatoractivated receptor gamma (PPargamma) as a novel target for prostate cancer. Investigative New Drugs 20 195-200.

Stendahl M, Kronblad A, Ryden L, Emdin S, Bengtsson NO \& Landberg G 2004 Cyclin D1 overexpression is a negative predictive factor for tamoxifen response in postmenopausal breast cancer patients. British Journal of Cancer 90 1942-1948.

Sugimura A, Kiriyama Y, Nochi H, Tsuchiya H, Tamoto K, Sakurada Y, Ui M \& Tokumitsu Y 1999 Troglitazone suppresses cell growth of myeloid leukemia cell lines by induction of p21WAF1/CIP1 cyclin-dependent kinase inhibitor. Biochemical and Biophysical Research Communications 261 833-837.

Takeda K, Ichiki T, Tokunou T, Ino N \& Takeshita A 2001 15Deoxy-delta 12,14-prostaglandin $\mathrm{J} 2$ and thiazolidinediones activate the MEK/ERK pathway through phosphatidylinositol 3-kinase in vascular smooth muscle cells. Journal of Biological Chemistry 276 48950-48955.

Takeuchi S, Okumura T, Motomura W, Nagamine M, Takahashi N \& Kohgo Y 2002 Troglitazone induces G1 arrest by p27(Kip1) induction that is mediated by inhibition of proteasome in human gastric cancer cells. Japan Journal of Cancer Research 93 774-782.

Tontonoz P, Hu E \& Spiegelman BM 1994 Stimulation of adipogenesis in fibroblasts by PPAR gamma 2, a lipid-activated transcription factor. Cell 79 1147-1156.

Tontonoz P, Singer S, Forman BM, Sarraf P, Fletcher JA, Fletcher CD, Brun RP, Mueller E, Altiok S, Oppenheim H et al. 1997 Terminal differentiation of human liposarcoma cells induced by ligands for peroxisome proliferatoractivated receptor gamma and the retinoid $\mathrm{X}$ receptor. PNAS 94 237-241. 
Tsubouchi Y, Sano H, Kawahito Y, Mukai S, Yamada R, Kohno M, Inoue K, Hla T \& Kondo M 2000 Inhibition of human lung cancer cell growth by the peroxisome proliferator-activated receptor-gamma agonists through induction of apoptosis. Biochemical and Biophysical Research Communications 270 400-405.

Wajant H 2003 Targeting the FLICE inhibitory protein (FLIP) in cancer therapy. Molecular Intervention 3 124-127.

Wang C, Fu M, D'Amico M, Albanese C, Zhou JN, Brownlee M, Lisanti MP, Chatterjee VK, Lazar MA \& Pestell RG 2001 Inhibition of cellular proliferation through IkappaB kinase-independent and peroxisome proliferator-activated receptor gamma-dependent repression of cyclin D1. Molecular and Cellular Biology 21 3057-3070.

Westwick JK, Lambert QT, Clark GJ, Symons M, Van Aelst L, Pestell RG \& Der CJ 1997 Rac regulation of transformation, gene expression, and actin organization by multiple, PAK-independent pathways. Molecular and Cellular Biology 17 1324-1335.

Wilcken NR, Prall OW, Musgrove EA \& Sutherland RL 1997 Inducible overexpression of cyclin D1 in breast cancer cells reverses the growth-inhibitory effects of antiestrogens. Clinical Cancer Research 3 849-854.

Wu K, Wang C, D'Amico M, Lee RJ, Albanese C, Pestell RG \& Mani S 2002 Flavopiridol and trastuzumab synergistically inhibit proliferation of breast cancer cells: association with selective cooperative inhibition of cyclin D1-dependent kinase and Akt signaling pathways. Molecular Cancer Therapeutics 1 695-706.

Yin F, Wakino S, Liu Z, Kim S, Hsueh WA, Collins AR, Van Herle AJ \& Law RE 2001 Troglitazone inhibits growth of MCF-7 breast carcinoma cells by targeting G1 cell cycle regulators. Biochemical and Biophysical Research Communications 286 916-922.

Yoshizawa K, Cioca DP, Kawa S, Tanaka E \& Kiyosawa K 2002 Peroxisome proliferator-activated receptor gamma ligand troglitazone induces cell cycle arrest and apoptosis of hepatocellular carcinoma cell lines. Cancer $\mathbf{9 5}$ 2243-2251.

Yu J, Qiao L, Zimmermann L, Ebert MP, Zhang H, Lin W, Rocken C, Malfertheiner P \& Farrell GC 2006 Troglitazone inhibits tumor growth in hepatocellular carcinoma in vitro and in vivo. Hepatology 43 134-143.

Yu Q, Geng Y \& Sicinski P 2001 Specific protection against breast cancers by cyclin D1 ablation. Nature 411 1017-1021.

Zwijsen RM, Wientjens E, Klompmaker R, van der Sman J, Bernards R \& Michalides RJ 1997 CDK-independent activation of estrogen receptor by cyclin D1. Cell $\mathbf{8 8}$ 405-415. 
